$\stackrel{\odot}{\text { II }}$

\title{
CO WYNIKA Z BADAŃ OPARTYCH NA DOWODACH DLA DALSZEGO ROZWOJU NAUK SPOKECZNYCH?
}

ABSTRACT. Stanisław Kowalik, Co wynika z badań opartych na dowodach dla dalszego rozwoju nauk społecznych? [How does evidence-based research affect the future development of social sciences?] edited by M. Obrębska, G. Dziamski, „Człowiek i Społeczeństwo" vol. XLIX: Humanistyka jutra [Humanities of Tomorrow], Poznań 2020, pp. 135-165, Adam Mickiewicz University. ISSN 0239-3271.

Global social order calls for more and more knowledge of applicable character. As a result, medicine developed certain procedures known as evidence-based research and evidence-based practice. Both procedures are promoted with great intensity in the domain of social sciences. The article demonstrates that such a type of modernisation may pose a threat to social sciences and their development. An alternative model of conducting research in the field of social sciences has been presented, which would guarantee an increase in the regulatory scientific knowledge in relation to the practice and which, at the same time, would protect social sciences against excessive political and economic interference in its further development.

Stanisław Kowalik, Akademia Wychowania Fizycznego im. Eugeniusza Piaseckiego w Poznaniu, Wydział Nauk o Kulturze Fizycznej, Zakład Adaptowanej Aktywności Fizycznej, ul. Królowej Jadwigi 27/39, 61-871 Poznań, kowalik@awf.poznan.pl.

\section{Wstęp}

Prowadząc badania naukowe w określonym czasie historycznym, często ulegamy złudzeniu, że to, co robimy, czynimy w najlepszy możliwy sposób. Często podziwiamy dokonania badaczy działających w przeszłości, specjalnie nie zastanawia nas jednak to, że do wielkich odkryć i wynalazków dochodzili oni przy stosowaniu metod, które należałoby odrzucić w świetle współczesnych standardów. Czy za wiarygodną można uznać 
metodę, jaką posługiwał się Karol Darwin, tworząc zręby teorii ewolucji? Wycinkowe badania paleontologiczne na niewielkim terenie Anglii, a potem obserwacje fauny i flory w czasie podróży słynnym żaglowcem, którego trasa nawet nie była wyznaczona celami badawczymi wielkiego biologa, dostarczyła mu informacji mało wiarygodnych, uzyskiwanych przypadkowo (Barlow, 1958). A jednak, dysponując tylko takimi danymi, skonstruował on podstawy współczesnych nauk biologicznych. Czy za wiarygodną metodę badawczą można uznać skrupulatne i wnikliwe analizy kilku przykładowych zdarzeń społecznych, które przytrafiły się Europie za życia Karola Marksa? Prawdą jest to, że z wielkim mozołem i wnikliwością studiował opisy, jakie zamieszczano w gazetach, a także sięgał do dzieł wcześniejszych teoretyków ekonomii (Wheen, 2005). Czy to jednak zostałoby dziś uznane za rzetelną metodę naukową, która uwiarygodnia stworzoną przez niego teorię ekonomiczną kapitalizmu? W tej sprawie można mieć wątpliwości. A przecież trudno sobie wyobrazić obecne nauki ekonomiczne bez pojęć stworzonych przez Marksa: środków produkcji, alienacji robotników, sił wytwórczych, a przede wszystkim kapitału. A jaką metodą posłużył się Zygmunt Freud? Wystarczyło mu przeanalizowanie zachowań kilkunastu pacjentów cierpiących na nerwice, aby zaproponować oryginalną koncepcję psychologicznego funkcjonowania ludzi, z którą do dziś muszą liczyć się wszyscy badacze zajmujący się poznaniem człowieka (Gay, 2003). Wykorzystywane przez niego dane empiryczne były z pewnością skromne pod względem ilościowym, a także ich wiarygodność może budzić dziś duże wątpliwości.

Wyliczanie badaczy, którzy wstrząsnęli fundamentami wiedzy powszechnie uznawanej za wartościową naukowo, a jednocześnie stosowali metody istotnie odbiegające od współczesnych standardów naukowych, można byłoby kontynuować (Arystoteles, Pasteur, Kartezjusz, Galileusz itd.). O każdym z tych przypadków można byłoby powiedzieć, że gdyby tę wiedzę przedstawiono obecnie, to ze względu na zastosowane metody (albo ich brak), zostałaby ona uznana za wiedzę pseudonaukową. Zgodnie z poglądem Mario Bunge (1985) pseudonaukę stanowią takie poglądy, które przedstawiane są jako prawdziwe ze względu na uzasadniające je dowody empiryczne, uzyskane przy zastosowaniu odpowiedniej metody naukowej, gdy faktycznie dowodów takich nie ma albo mają wątpliwą wartość w zakresie weryfikacji słuszności tych poglądów.

Stosowane kiedyś kryteria naukowości obecnie uległy zasadniczym zmianom. Z tego punktu widzenia każdego z trzech wymienionych wcześniej badaczy - Darwina, Marksa i Freuda - można byłoby potraktować 
jako twórcę pseudonauki. Niektórzy krytycy teorii ewolucji, teorii walki klas społecznych, teorii działania nieświadomości tak czynią, zarzucając im albo cwaniactwo społeczne, albo fanatyzm ideologiczny, czyli intencjonalne albo pozaintencjonalne wprowadzanie w błąd tych wszystkich, których nauka interesuje (Thyer, Pignotti, 2015). Na szczęście więcej jest tych, którzy doceniają wartość dokonań wybitnych uczonych, mimo wątpliwości związanych ze stosowanymi przez nich metodami badawczymi. Jeśli więc spojrzymy historycznie na rozwijającą się wiedzę naukową, to nieodmiennie pojawi się pytanie: co rozstrzyga o uznaniu danej wiedzy za naukową albo pseudonaukową i kto decyduje o takim albo innym jej zaklasyfikowaniu? Na to pytanie będę starał się odpowiedzieć w tym opracowaniu, biorąc pod uwagę wszystkie zmiany, jakie pojawiły się ostatnio w badaniach naukowych, wymuszone przez procesy globalizacyjne.

\section{Dlaczego globalizacja wymusza wprowadzanie zmian w realizacji badań naukowych?}

W zasadzie od wieków w świadomości społecznej pojawiały się pomysły na idealne urządzenie świata, w którym każdy człowiek czułby się szczęśliwy. Już Owidiusz widział taką możliwość. Słynne Metamorfozy zaczyna on od słów: „Przemiany pragnę śpiewać ciał w odmienne ciała”. Owidiuszowi chodzi oczywiście nie tyle o ciała, co o ludzi doskonalących się w taki sposób, aby życie każdego z nich było lepsze. Przyjmował on, że ludzki los znajduje się w rękach bogów, dlatego do nich zwracał się z prośbą o taką przemianę. Ostatnim myślicielem, który zaprojektował utopijną wizję lepszego świata, był chyba wspomniany wcześniej Marks. W wielu pismach, z Manifestem komunistycznym na czele, przedstawiał propozycję tworzenia społeczeństwa, w którym będzie dane „Każdemu według swych zdolności, każdemu według jego potrzeb”. Tym razem to nie bogowie, ale proletariat miał doprowadzić do powszechnej szczęśliwości ludzi żyjących w warunkach komunizmu.

Trudno dziś powiedzieć, czy tworzona na naszych oczach globalizacja światowa, będąca urzeczywistnieniem marzeń neoliberalnych ideologów, okaże się kolejną utopią, czy też rzeczywiście uda się zrealizować ją w pełni, dając szansę na lepsze, bardziej satysfakcjonujące życie (Peck, Tickell, 2002). Na razie można stwierdzić, że na obecnym poziomie jej wdrażania następuje przemiana ludzkiego życia we wszystkich jego wymiarach, ale trudno określić ich trwałość. Według Johna A. Scholtego (2000) najwyraźniejsze trendy 
zmian wywołanych globalizacją polegają na: a) takim dowartościowaniu zasad życia i wytwarzanych dóbr amerykańskich, aby reszta świata uznawała je za najlepsze i z nich korzystała, odchodząc od własnych tradycji (westernizacja), b) ułatwianiu wymiany tych dóbr i innych osiągnięć cywilizacji Zachodu poprzez rozbudowę możliwości transportowych i komunikacyjnych (deterytorializacja), c) tworzeniu warunków do uzyskiwania podobnych doświadczeń społecznych przez większość ludzi żyjących w podobnym, zglobalizowanym świecie (uniwersalizacja) oraz d) umożliwieniu korzystania przez wszystkich ludzi z nowych warunków życia w taki sposób, aby każdy miał podobne szanse na kształtowanie przebiegu własnego losu (liberalna indywidualizacja).

Łatwo można zauważyć, że apologeci globalizacji opierają wizję przebudowy społecznego świata na założeniu, że tylko to, co zostało stworzone na Zachodzie, może być gwarancją uzyskania pomyślnego rozwoju dla całej ludzkości, ponieważ każde działanie podjęte tam właśnie cechuje się wysokim poziomem racjonalności. Tak więc do wyżej wymienionych cech globalizacji należy dodać jeszcze jedną - racjonalność funkcjonowania całej globalnej struktury życia społecznego (Caselli, 2012; Petras, 1999). Dzięki racjonalności działań możliwe jest uzyskiwanie dóbr najwyższej jakości. Ponieważ produkuje się je w dużych ilościach, mają stosunkowo niskie ceny - więc dostępne są dla każdego. Eliminowane są oferty tworzone poza rynkiem globalnym, ponieważ nie mają takiej promocji i reklamy jak te, których wytwarzanie finansuje globalny kapitał (Kowalik, 2015). Dotyczy to w takim samym stopniu dóbr ekonomicznych, jak i dóbr kultury. W takiej sytuacji następuje upodobnienie życia ludzi - korzystają z takich samych dóbr, preferują podobny racjonalny sposób życia, a nawet oceniają własne osiągnięcia na podstawie identycznych kryteriów. Warto zauważyć, że jest to niezgodne z lansowaną w ramach globalizacji obietnicą, że każdy człowiek może rozwijać swoją indywidualność w pełnej wolności, a więc globalizacja powinna prowokować wzrost różnorodności w ludzkim życiu nie ma dowodów, że w takim kierunku zmienia się ład społeczny (Lubeck, Jessup, 2001). Wręcz odwrotnie, podporządkowanie przebiegu życia zasadzie racjonalności doprowadza do narzucenia wszystkim uniwersalnych wzorców postępowania, a ludzie to akceptują. Jak napisał Mervyn F. Bendle (2001), przyjmują oni bezrefleksyjnie powtarzający się ciągle przekaz, że: „Nie ma lepszego świata poza światem globalnym. Masz w nim wszystko, czego potrzebujesz i co jest najlepsze” (s. 83).

Obietnica globalizacyjna, że dzięki upowszechnieniu racjonalnych działań na poziomie społecznym i jednostkowym uzyskamy niepowtarzalną 
możliwość zrealizowania od dawna formułowanych utopijnych marzeń, nobilituje wiedzę naukową na niespotykaną wcześniej skalę (Sindermann, 1985). Tylko poprzez odwołanie się do niej można bowiem zapewnić racjonalność życia. Wiedza ta zawiera zdobyte poprzez badania naukowe wszelkie informacje o prawidłowościach, które obowiązują w świecie fizyczno-przyrodniczym i społeczno-psychologicznym. Racjonalność działania polega na bezwzględnym respektowaniu tych prawidłowości, a tym samym wykorzystaniu ich w optymalny sposób w życiu pojedynczych ludzi i zbiorowości. Tym samym można unikać błędów, a wysiłek włożony w działanie powinien gwarantować uzyskanie pożądanych efektów w stopniu najwyższym (Bhagwati, 2007). Globalizacji potrzeba więc jak najwięcej wiarygodnej wiedzy, aby wykorzystać ją w organizowaniu racjonalnych działań. Równocześnie niezbędna jest edukacja ludzi tworzących globalne społeczeństwo. Dzięki niej wszyscy mogą zapoznać się z identyczną wiedzą naukową, która zastępuje zróżnicowaną wiedzę potoczną.

Życie w globalnym społeczeństwie bez posiadania odpowiednich zasobów wiedzy naukowej jest niemożliwe. Warunkiem istnienia globalizacji jest więc stworzenie społeczeństwa wiedzy. Można przyjąć, że charakteryzuje się ono następującymi właściwościami:

- jego członkowie dysponują zbliżonym poglądem na świat, który można określić jako naukowy. Każdy inny zbiór uznawanych przekonań wykraczających poza naukową dopuszczalność - traktowany jest jako wyraz ignorancji ich właścicieli. Społeczeństwo wiedzy charakteryzuje się tak zwaną poprawnością myślenia i wynikającą z niej poprawnością działania;

- poglądy na świat ludzi należących do społeczeństwa wiedzy nie mają osobistego charakteru. W znikomym tylko stopniu wyrażają one prywatne doświadczenia ludzi, a stopniu zasadniczym są odwzorowaniem obiektywnej wiedzy naukowej; obiektywnej ze względu na fakt, że jest ona powszechnie akceptowana. Tym samym w tej wiedzy minimalizowana jest informacyjna wartość emocji - mówiąc potocznie, ludzie kierują się w swoim postępowaniu rozumem, a nie sercem;

- większość członków społeczeństwa wiedzy przejmuje poglądy naukowe w sposób mało krytyczny. Oznacza to, że przeciętny członek takiego społeczeństwa nie ma wątpliwości co do wiarygodności informacji uzyskiwanych od naukowców. Kieruje się uzyskaną wiedzą w sposób bezrefleksyjny, ale też bez przyjęcia osobistej odpowiedzialności za rezultaty swoich działań. Wierzy, że jego postępowanie musi być racjonalne, jeśli opiera się na wskazówkach, jakich dostarcza mu nauka (Böhme, Stehr, 1986; Cavallo, 1979; Kurz-Milcke, 2004; Rakel, 2004). 
Globalizacyjny postulat tworzenia społeczeństwa wiedzy zrównuje ze sobą racjonalność naukową z racjonalnością społeczną. Wszyscy dążą do profesjonalizmu nie tylko w pracy zawodowej, ale też w życiu prywatnym (chcemy żyć mądrze, czyli racjonalnie). Zaciera się granica między poznaniem naukowym i korzystaniem z jego rezultatów. Każdy, kto tylko chce, może sam wykonać badanie i na podstawie uzyskanych informacji rozwiązywać własne problemy w racjonalny sposób (zarządzać firmą, podejmować decyzje na poziomie lokalnych samorządów, prowadzić kampanię reklamową, oferować nowe usługi lecznicze itd.). Ten proces powszechnego odwoływania się do wiedzy naukowej (ale niekoniecznie do autorytetów naukowych) przy podejmowaniu różnorodnych decyzji określany jest jako scjentyzacja życia społecznego (Rakel, 2004). Helga Nowotny (1979) nieco złośliwie porównuje tę nową rolę przypisywaną nauce do instytucji opieki społecznej. Traktuje ona ludzi, jakby byli niepełnosprawni umysłowo i nie potrafili właściwie kierować swoim postępowaniem, dlatego też dostarcza im odpowiedniej wiedzy w celu zmniejszenia ograniczeń w zakresie rozsądnego myślenia. W celu ułatwienia tego procesu ludzie otrzymują wiedzę naukową w postaci gotowych instrukcji matrycowych, które podpowiadają im, jakie poglądy na temat rzeczywistości są uprawnione i jakie działania we wszystkich obszarach życia są właściwe (Walter, 2004). Nauka likwiduje więc poczucie niepewności społecznej w odniesieniu do każdej dziedziny życia, ale żeby sprostać oczekiwaniom społecznym, musi intensywnie rozwijać się w określonym kierunku, takim mianowicie, który polega na tworzeniu wiedzy użytecznej dla dalszego rozwoju globalizacji.

\section{Co proponują nowe rozwiązania w zakresie uprawiania nauki?}

W ciągu pięćdziesięciu lat działalności naukowej mogłem obserwować proces transformacji, jaki dokonał się w tej dziedzinie. Nie jest to tylko moje osobiste doświadczenie. Radykalne zmiany w prowadzeniu badań naukowych są zauważane powszechnie. Przy czym niektórzy badacze zmiany te oceniają pozytywnie, a inni negatywnie (Hamill, Wiener, 2018; Wright, Hibbert, Greenfield, 2018). Starsi z nich podkreślają, że nastąpiło całkowite zerwanie z tradycją prowadzenia badań naukowych, a młodsi nie zdają sobie nawet sprawy z tego, że zajmowanie się nauką może wyglądać inaczej niż ich obecna praca badawcza - nie mając punktu odniesienia, a więc podporządkowują się wymaganiom, jakie postawiła przed nauką globalizacja. Na czym polega różnica w prowadzeniu badań naukowych dawniej i obecnie? 
W zasadzie od czasów Arystotelesa rola nauki została jasno określona. Swoją Fizykę rozpoczyna Stagiryta znamiennymi słowami: „Skoro przy wszelkich roztrząsaniach, dla których istnieją zasady czy przyczyny lub elementy, wiedza i rozumienie wynikają właśnie z ich znajomości (wtedy bowiem sądzimy, żeśmy daną rzecz poznali, gdyśmy wykryli jej pierwsze przyczyny i pierwsze zasady aż do ostatecznych elementów), jasne się staje, że i w poznawaniu przyrody najpierw trzeba próbować określić owe pierwsze zasady” (Arystoteles, 1990: 23). Zgodnie z tym poglądem zadaniem naukowców jest wnikanie w te sfery rzeczywistości, które są ukryte pod jej powierzchnią. Nie wystarcza im rejestrowanie tego, co rzeczywistość odsłania zmysłom. Muszą - wykorzystując myślenie - wyjaśnić, dlaczego ta powierzchnia rzeczywistości przedstawia się w taki właśnie sposób. Dzięki temu mogą dojść do odkrycia naukowego, czyli wysunięcia przypuszczeń (hipotez) odnośnie zależności przyczynowo-skutkowych między tym, co jest dostrzegalne zmysłowo, a tym, co prawdopodobnie decyduje o widocznych atrybutach rzeczywistości (Sintonen, Kiikri, 2004). Informacje percepcyjne wykorzystywane są więc do tworzenia pełniejszego (uwzględniającego to, co jest niedostrzegalne) obrazu rzeczywistości, ale są niewystarczające. Trzeba dodatkowo posłużyć się pojęciami teoretycznymi, które pomagają wyjaśnić, dlaczego rzeczywiste stany, zjawiska, procesy wyglądają tak, a nie inaczej. Oczywiście wiedza teoretyczna powinna być jeszcze odpowiednio potwierdzona empirycznie. Wtedy dopiero osiągnięty zostanie podstawowy cel badań naukowych - uznanie, że stworzony obraz rzeczywistości zbliżony jest do niej samej, czyli uznajemy go za prawdziwy na danym etapie rozwoju wiedzy naukowej (Audi, 2004).

W tym ujęciu nauka ma skupiać się na możliwie prawdziwym rekonstruowaniu rzeczywistości, a jej efektem powinny być - niebudzące wątpliwości i precyzyjnie sformułowane przy użyciu specjalistycznego języka - spójne zbiory poglądów na jej temat (obrazy rzeczywistości). Chciałbym w tym miejscu podkreślić, że nic nie powinno zakłócać procesu naukowego dochodzenia do prawdy. Obowiązkiem naukowców zawsze było maksymalne izolowanie przebiegu swojej pracy od wpływów własnego doświadczenia życiowego, a także innych dystraktorów społecznych (Brzeziński, 1978). Efekty odkrycia naukowego powinny być udostępnione wszystkim zainteresowanym, aby mogli oni zbadać, czy proponowana wiedza jest rzeczywiście nowatorska i prawdziwa (intersubiektywna komunikowalność). Za to naukowcy biorą społeczną odpowiedzialność, natomiast nie zależy już od nich to, jak tą wiedzą będą posługiwali się inni (Møller, Huschka, 2009). 
Oczywiście od przedstawionego opisu klasycznego pojmowania działalności naukowej zdarzały się różne odchylenia. Toczone były i nadal są spory odnośnie tego, jak należy rozumieć proces wyjaśniania, czy odkrycie naukowe musi opierać się na hipotezach, jaki jest status niektórych nauk, które nie zajmują się dochodzeniem do prawdy (na przykład nauki politechniczne zajmujące się wynalazkami, czyli wzbogacaniem rzeczywistości, albo prawo zajmujące się normowaniem współżycia społecznego). To jednak były mało szkodliwe aberracje, które nie zmieniały istoty badań naukowych. Ta nastąpiła dopiero pod wpływem globalizacji, stawiającej nauce nowe zadania, o których wspomniałem w poprzednim paragrafie. Zerwanie z tradycją prowadzenia badań naukowych można sprowadzić do trzech haseł: utylitaryzmu badawczego, biurokratyzmu naukowego i standaryzacji umysłów ludzi zajmujących się badaniami. Pod kątem tych haseł krótko scharakteryzuję globalizacyjne podejście do nauki.

Ponieważ rozwój globalizacji zależy od tego, czy uda się wyeliminować przypadkowość (przygodność) z życia społecznego, a tym samym uczynić je maksymalnie przewidywalnym, dąży się do przekształcenia nauki w technologię zapewniającą dokonywanie trafnych wyborów działania, które mają służyć rozwiązywaniu różnych problemów społecznych i jednostkowych (Ullrich, 1979). W mniejszym stopniu oczekuje się od badań naukowych wyjaśniania stanów i procesów zachodzących w rzeczywistości, a w większym stopniu prognozowania, co może zdarzyć się w przyszłości i jakie czynniki należy wykorzystać, aby uczynić ją doskonalszą (z punktu widzenia realizacji celów globalizacyjnych). Poznanie naukowe sprowadzone zostaje do rozpoznania tak zwanych predyktorów, które w sposób istotny determinują możliwość wywołania pożądanych stanów w rzeczywistości. Są one oparte na badaniach empirycznych, które jednak u swoich podstaw nie mają koncepcji teoretycznych, lecz tak zwane empiryczne modele prognostyczne zawierające zestawy czynników, które mogą determinować wystąpienie interesującego nas zjawiska albo procesu (Coleman, 1968; Dunn, Elliott, 2008). Jak widać, nastąpiła podstawowa zmiana w zakresie zapotrzebowania na rodzaj wiedzy naukowej. Idea Arystotelesa, że nauka będzie stopniowo tworzyła coraz prawdziwszy i spójniejszy obraz rzeczywistości (ze względu na odkrycie uniwersalnych, tak zwanych pierwszych prawidłowości organizujących rzeczywistość), przestała być aktualna. Zamiast niej pojawiła się idea globalizacyjna - nauki udzielającej niezawodnych wskazówek, dotyczących podejmowania takich działań, które zagwarantują realizację zakładanych celów społecznych. To jest istota utylitaryzmu badawczego zamiast dochodzenia do wiedzy prawdziwej, proponuje on dochodzenie 
do wiedzy przydatnej w podejmowaniu racjonalnych decyzji w różnych obszarach praktyki społecznej (Brohman, 1995).

Powodzenie tak realizowanych badań naukowych może zapewniać wprowadzenie możliwie ścisłej kontroli administracyjnej nad badaniami (Böhme, 1979). Oczywiście stwarzane jest wrażenie, że nauka nadal jest wolna i niezależna od jakichkolwiek wpływów. Faktycznie jednak kierunki jej rozwoju zależą ściśle od polityki finansowania nauki. Stosunkowo łatwo można otrzymać pieniądze na realizację projektów badawczych ukierunkowanych na zdobycie wiedzy praktycznie użytecznej. Kryteria awansów naukowych także zależą od liczby wykonanych projektów i punktów uzyskanych za publikacje. A do druku najchętniej przyjmuje się opracowania o charakterze empirycznym. Mniej cenione są analizy teoretyczne, proponujące nowatorskie, twórcze poglądy na jakiś temat, niż doniesienia o wynikach uzyskanych w sprawnie przeprowadzonych eksperymentach lub badaniach ankietowych sprawiających wrażenie, że mogą udoskonalić jakieś praktyczne działanie. Szczególne zainteresowanie aplikacyjnymi wynikami badań przyczynia się niewątpliwie do upolitycznienia nauki. Politycy dążą do sprawowania nad nią biurokratycznej kontroli nie tylko z powodów ideowych (budowanie społeczeństwa wiedzy), ale także w celu wykorzystania jej we własnych interesach (Marttila, 2016). Warto dodać, że biurokratyzmowi naukowemu przez pewien czas przeciwstawiali się badacze kultywujący dawny etos nauki. Nazywano ich słusznie autorytetami naukowymi (Ruane, 2014). Dzięki oryginalnej twórczości, zaangażowaniu w rozwój instytucji naukowych i kształcenie młodych badaczy to właśnie oni decydowali o losach nauki. Byli swoistym depozytem wartości naukowych przekazywanych z pokolenia na pokolenie (obowiązywała zasada „mistrzuczeń”). Dziś można już stwierdzić, że biurokracja naukowa poradziła sobie skutecznie z tymi autorytetami, niewątpliwie utrudniającymi wprowadzenie badań naukowych na nowe globalizacyjne tory. A zamiast autorytetów pojawili się na uczelniach eksperci, komercyjnie eksploatujący posiadane kompetencje badawcze (Kowalik, 2006).

Biurokratyczny nadzór nad badaniami naukowymi nie jest sprawą łatwą. Nawet rozbudowanie kadr administracyjnych zajmujących się wycenianiem wartości różnych czasopism naukowych, wydawnictw, uczelni, dyscyplin naukowych, patentów i projektów badawczych oczekujących na odpowiednie dofinansowanie nie wystarcza w sytuacji, gdy tak zwana produkcja naukowa rozwija się na niespotykaną wcześniej skalę (Hallowell, Lawton, Gregory, 2005). W tej sytuacji wymyślone zostało świetne rozwiązanie, które ułatwia ocenę wartości pracy badawczej. Polega ono 
na wprowadzeniu różnorodnych standardów, pomocnych w rozstrzyganiu, co jest dobre, a co jest złe w twórczości naukowej. Systematycznie dąży się do tego, aby te formalne wymogi doprecyzować, co ma służyć zwiększeniu obiektywności dokonywanych ocen. Ustala się, jak powinna wyglądać struktura artykułu naukowego, jak należy przygotować referat wygłaszany na konferencji, na co zwracać uwagę przy określaniu wartości czasopisma naukowego. Ostatnio zdumiały mnie zalecenia kierowane do naukowców, które określają, jakie teksty powinni oni czytać i na co powinni zwracać uwagę w trakcie ich czytania (Greenhalgh, 2001). Wprowadzenie ścisłych standardów do każdego obszaru pracy badawczej jest ułatwieniem nie tylko dla kontrolerów oceniających wartość prac naukowych, ale też dla naukowców. Mogą dostosować się do administracyjnych oczekiwań. Prowadząc badania, skupiają się przede wszystkim na tym, aby były one zgodne ze standardami. Mniej istotne jest to, co oryginalnego wnoszą do wiedzy naukowej, gdyż twórczych odkryć naukowych nie da się tak łatwo ocenić na podstawie jakichś standardów. W ten sposób zewnętrzne wzorce pracy naukowej - narzucane administracyjnie - ulegają uwewnętrznieniu. Młodzi badacze z łatwością przyswajają nowe kompetencji, ponieważ nie znają alternatywy, a poza tym ułatwiają one sprawne publikowanie tekstów naukowych (w dużej liczbie i w zgodzie z oczekiwaniami biurokratycznymi). Umysł standardowy badacza to jednak umysł konformistyczny. Znacznie trudniej jest przy jego pomocy tworzyć autentycznie nową wiedzę naukową. Warto w tym miejscu zacytować pogląd Jürgena Habermasa (1992), który proroczo przewidział, że nauka (a szczególnie nauki społeczne): „trudni się oczyszczaniem praktycznej świadomości grup społecznych z teorii, których nie można sprowadzić do wiedzy tylko technicznie użytecznej, a która [wiedza techniczna - uzupełnienie S.K.] zarazem wysuwa roszczenia teoretyczne” (s. 106). Ten oczyszczający trud w całej pełni odnosi się też do środowiska naukowców.

\section{Czym jest „działalność naukowa oparta na dowodach"?}

Nową formą prowadzenia badań naukowych - lansowaną ostatnio z wyjątkowym uporem i intensywnością - jest działalność naukowa oparta na dowodach i jej wykorzystanie w praktyce (evidence-based research and practice). Odpowiada ona w pełni postulatom wysuwanym wobec nauki przez apologetów globalizacji. Pełni też skutecznie funkcję „,czyściciela” umysłów naukowców z myślenia teoretycznego i przyzwyczaja ich do posługiwania 
się biurokratycznymi standardami w pracy badawczej. Łatwo można zauważyć, że w tym przypadku tak naprawdę chodzi o dwie procedury: evidence-based research i evidence-based practice (Singh, Oswald, 2004a). Należy je wyraźnie odróżniać od siebie, chociaż są tak ściśle połączone ze sobą, iż trudno byłoby realizować jedną bez udziału drugiej. Praktyka oparta na dowodach oznacza każde postępowanie, które jest w pełni zgodne z naukowo potwierdzonymi wcześniej, wiarygodnymi wynikami badań empirycznych (Malcolm, Taylor, Mitchell, Saile, Heathy, Alpert-Gillis, 2019). Natomiast badanie oparte na dowodach to każde badanie empiryczne wykonane zgodnie z określonymi standardami naukowymi, które ukierunkowane jest na weryfikację skuteczności danej praktyki oraz przyczynia się do wyboru najskuteczniejszych działań praktycznych (Sherwood, 2019). Zadziwiające jest samo określenie tych procedur. Moim zdaniem każda działalność naukowa musi opierać się na dowodach, jeśli chce dostarczyć wiarygodnej wiedzy. Podobnie jak większość praktycznych działań powinna mieć jakieś racjonalne, naukowe uzasadnienie. Zasady te obowiązywały w nauce od wieków. Co nowego w takim razie wnosi do postępowania badawczego ten nowy pomysł i jakie mogą być konsekwencje społeczne jego upowszechnienia? Tylko szczegółowa analiza obu procedur pozwoli zorientować się, do czego może doprowadzić globalizacyjna ingerencja w rozwój nauki.

Po raz pierwszy pojęciem „praktyka medyczna oparta na dowodach” posłużyli się pracownicy Wydziału Epidemiologii Klinicznej Uniwersytetu McMaster w Kanadzie. Było to stosunkowo niedawno, bo w 1981 roku. Tam też podjęte zostały pierwsze badania, które miały na celu precyzyjne określenie najskuteczniejszych procedur leczenia różnych chorób (Singh, Oswald, 2004a). Uznano, że wiedza z zakresu patofizjologii, genetyki, biochemii, psychologii nie jest wystarczająca, a nawet nie jest przydatna jako podstawa naukowa postępowania leczniczego dla klinicystów, którzy mają do czynienia z konkretnymi przypadkami osób chorych. Medycyna oparta na dowodach została określona jako: „Staranne, precyzyjne i rozważne posługiwanie się aktualnie najlepszymi dowodami w podejmowaniu decyzji związanych z leczeniem indywidualnych pacjentów” (Sackett, Rosenberg, Gray, Haynes, Richardson, 1996: 71). Tę propozycję można uznać za racjonalną, szczególnie w medycynie, która nie dopracowała się własnych koncepcji teoretycznych, dotyczących rekonstrukcji procesów przechodzenia organizmu ze stanu zdrowia do stanu choroby i odwrotnie. Procedura leczenia oparta na dowodach miała na celu zaspokojenie w większym stopniu oczekiwania pacjentów odnośnie trafności stawianych diagnoz medycznych i skuteczności zastosowanych zabiegów leczniczych. 
Aby osiągnąć te cele, postulowano: a) możliwie precyzyjne sformułowanie problemu medycznego (nie powinien być nadmiernie konkretny, ale też nie może być ogólnikowy), b) zapoznanie się w pełni z dostępną literaturą fachową, która prezentuje wyniki badań empirycznych dotyczących postępowania leczniczego pacjentów z określonym problemem zdrowotnym (co nie jest trudne przy zastosowaniu specjalistycznych wyszukiwarek internetowych), c) dokonanie krytycznego wartościowania informacji zawartych w fachowych artykułach (chodzi o ich ocenę ze względu na poprawność metodologiczną wykonanych badań), d) wybieranie najskuteczniejszej terapii (na podstawie wyników badań), e) posłużenie się nią w sposób dokładnie taki, jak to zostało opisane w odpowiednim doniesieniu naukowym (bez jakichkolwiek odstępstw), f) monitorowanie efektów zastosowanego leczenia (z możliwością wykorzystania ich do dalszego korygowania terapii) (Singh, Oswald, 2004b).

Kate Aument i Quincy Conley (2018) podkreślają, że upowszechnienie opisanej procedury postępowania medycznego napotyka jednak na dwie poważne bariery. Pierwszą z nich jest brak czasu lekarzy na zapoznanie się z publikacjami odnoszącymi się do skuteczności leczenia poszczególnych chorób. Szacuje się, że do 2005 roku wszystkich opublikowanych artykułów z dowodami empirycznymi o skuteczności różnych terapii było mniej niż takich samych publikacji drukowanych w każdym kolejnym roku. Na dodatek, ciągle obserwuje się dynamiczny ich wzrost. Scott Eustace (2018) przykładowo obliczył, że specjalista w zakresie dermatologii powinien rocznie przeczytać 11 tysięcy artykułów ze swojej dziedziny. Należy dodać, że mimo dużej liczby publikacji ich rozkład nie pokrywa równomiernie poszczególnych obszarów medycyny. Niektóre cieszą się bardzo dużym zainteresowaniem badaczy, ale są też takie, które nie dysponują wystarczającym zapleczem dowodowym (na przykład choroby rzadkie). Druga bariera dotyczy małej wiarygodności publikowanych wyników badań. Chodzi o to, że bez doboru losowego osób badanych, bez stosowania grupy kontrolnej, bez rzetelnych i trafnych narzędzi pomiaru efektów leczenia, ale też bez dokładnego opisu stosowanych procedur leczniczych w odniesieniu do dokładnie opisanej grupy osób leczonych nie można uznać wyników badania za wiarygodne (Ercikan, Roth, 2016). W związku z tym wysiłek badawczy powinien być skoncentrowany na prowadzeniu badań naukowych, które spełniają określone rygory metodologiczne, a jeśli ich nie spełniają, to szkoda czasu na zapoznawanie się z ich wynikami (Straus, Richardson, Galszious, Haynes, 2005).

Wspomniane bariery utrudniające upowszechnianie medycyny opartej na dowodach wymusiły rozwój tak zwanych badań opartych na dowodach. 
Mają one na celu ułatwienie prowadzenia leczenia w sposób naukowo uzasadniony. W celu zwiększenia skuteczności leczenia naukowcy mają nie tylko weryfikować empirycznie wartość leczniczą konkretnych rodzajów terapii, ale także analizować całościowo zgromadzoną wiedzę na temat ich skuteczności (metaanalizy), odrzucać opracowania o wątpliwej wartości metodologicznej, tworzyć specjalnie sprofilowane bazy danych (na przykład Cochrane) i programy komputerowe wspomagające lekarzy w podejmowaniu decyzji leczniczych (Montori, Guyatt, 2008; Oakley, 2002; Olson, Young, Schultz, 2016). W celu zapewnienia możliwie wysokiego poziomu obiektywizmu tej pracy badacze pracujący w oparciu o dowody naukowe starają się działać zespołowo. Podejmowane decyzje poprzedzone są wszechstronnymi konsultacjami z ekspertami i lekarzami-praktykami. Brane jest pod uwagę bezpieczeństwo pacjentów poddanych danej terapii (Beauchamp, Drepeau, Dionne, 2015). Wreszcie wypracowywane są precyzyjne kryteria oceny wartości dowodowej wyników badań. Przykładowo klasyfikuje się je jako bardzo dobre (wielokrotne albo pojedyncze metaanalizy), dostateczne (pojedyncze badania z zastosowaniem grupy kontrolnej i kontrolą warunków zewnętrznych) i słabe (dobrze zaprezentowana kazuistyka i opinie ekspertów). Na tej podstawie specjaliści od badań opartych na dowodach przygotowują propozycje gotowych - ich zdaniem najlepszych - procedur leczniczych (Singh, Oswald, 2004a). Złośliwie można powiedzieć, że są to instrukcje przypominające trochę katechizm, określający niezawodny sposób dostania się do nieba. W przypadku instrukcji medycznych opartych na dowodach mają one pomóc w jak najpóźniejszym dotarciu do tego miejsca.

Medycyna oparta na dowodach wzbudziła zainteresowanie specjalistów w zakresie polityki zdrowotnej, głównie jednak firm zajmujących się ubezpieczeniami zdrowotnymi (Sherwood, 2019). Wynikało ono z pobudek ekonomicznych. Kanadyjska propozycja gwarantowała zwiększenie efektywności usług leczniczych poprzez wyeliminowanie z nich terapii o niewielkiej skuteczności, a jednocześnie droższych. Co więcej, instytucje ubezpieczeniowe uzupełniły dodatkowo kryteria dopuszczalności stosowania określonych terapii, wyrażające się w postulacie: wybieramy nie tylko takie leczenie, które jest skuteczne, ale też takie, które jest mniej kosztowne, a jednocześnie ma podobne właściwości lecznicze (Burgess, Chang, Nakamura, Izmirian, Okamura, 2016). Trzeba w tym miejscu dodać, że dodatkowym powodem szybkiego upowszechnienia się medycyny opartej na dowodach był dynamiczny wzrost alternatywnych, paranaukowych ofert leczenia, które nie miały nic wspólnego z racjonalnym postępowaniem. Empiryczne dowody naukowe miały pomóc w zlikwidowaniu tej działalności, żerującej na niewiedzy pacjentów. 
Nie chcę oceniać wartości naukowej pomysłu łączenia ze sobą praktycznego działania ze specyficznie pojmowaną wiedzą naukową, jaki pojawił się w środowisku medycznym. Niewątpliwie odpowiadał on w pełni oczekiwaniom stawianym wobec nauki przez zwolenników globalizacji. To było właśnie to, czego potrzebowali do tworzenia społeczeństwa wiedzy, które racjonalnie, a więc także skutecznie potrafi rozwiązywać trapiące je problemy. Nic dziwnego, że praktykę i badania oparte na wiedzy próbuje się wdrożyć w wielu innych dyscyplinach naukowych, w tym także w naukach społecznych.

\section{Jakie można mieć wątpliwości w związku ze stosowaniem w naukach społecznych procedur opartych na dowodach?}

Dość szczegółowo opisałem procedury prowadzenia badań opartych na dowodach i ich wykorzystywanie w praktyce lekarskiej. Zrobiłem to, aby mieć dobry punkt wyjścia do ukazania, co może wynikać z tej propozycji dla dalszego rozwoju nauk społecznych. Niewątpliwie pozycja tych nauk stopniowo obniża się wraz z rozwojem globalizacji (MacCoun, 2015). Powodem tej degradacji jest przede wszystkim trudność wykazania wobec biurokracji naukowej, że wyniki badań tworzonych w tych naukach można w prosty sposób wykorzystać do doskonalenia życia społecznego. W każdym razie ich przydatność społeczna nie jest taka, jakiej oczekiwaliby krzewiciele globalizacyjnego porządku społecznego. W tej sytuacji badacze reprezentujący nauki społeczne mają dwa wyjścia. Pierwsze z nich polega na dokonaniu takiej modernizacji własnych badań naukowych, aby odpowiadały one biurokratycznym oczekiwaniom. Proces ten już się zaczął. Jak podaje Anthony Giddens (2009), w Unii Europejskiej jest on niezbędny, ponieważ: „ponad 80\% ludzi musi utrzymywać się z pracy ma stanowiskach wymagających specjalistycznej wiedzy. [...] Ma to jednak swoją cenę. Ponad dwie trzecie miejsc pracy stworzonych w gospodarce opartej na wiedzy wymaga wyszkolenia praktycznego i proporcja ta rośnie” (s. 39). W socjologii, ekonomii, pedagogice, kulturoznawstwie, nauce o zarządzaniu, prawie, politologii, a szczególnie w psychologii pojawia się coraz więcej opracowań wzorujących się na medycznym evidence-based (Cairney, 2016). Drugie wyjście można określić jako kontynuację dotychczasowych sposobów prowadzenia badań w poszczególnych dyscyplinach przynależących do nauk społecznych. W tym przypadku nie chodziłoby jednak o prostą kontynuację, ale taką, która uwzględniałaby wymóg uczestnictwa tych nauk w kształtowaniu 
społeczeństwa wiedzy, przeprowadzaną jednak na własnych warunkach. Opowiadam się za drugim wyjściem i dlatego w dalszej części tego opracowania skupię się na pokazaniu alternatywnych w stosunku do evidence-based możliwościach zwiększania przydatności praktycznej nauk społecznych.

Warto może przypomnieć, że nauki społeczne nigdy nie traciły z pola widzenia aplikacyjnych funkcji, jakie miały do wypełnienia. Nie trzeba sięgać daleko, aby uzasadnić tę tezę. W pierwszych latach XX wieku wybitny prawoznawca Leon Petrażycki (1985) pisał: „Obecnie ludzie w bardzo wielu dziedzinach życia pozbawieni są takiego światła naukowego, błądzą w ciemnościach i popełniają dużo szkodliwych, czasem zgubnych i niedających się poprawić błędów, a w każdym razie nie osiągają takich rezultatów, jakie mogłyby być osiągnięte przy istnieniu należytego kierownictwa naukowego" (s. 127). Pisał również: „Największą wartość [...] przedstawia wiedza teoretyczna, dotycząca klas, przedmiotów i zjawisk, ich natury, składu własności przyczynowych, tj. zdolności działania w określony sposób, wywoływania określonych innych zjawisk, określonych efektów przyczynowych” (s. 123). Zgodnie z tym stanowiskiem, chociaż wiedza teoretyczna nie formułuje wprost „prawideł rozumnego postępowania”, to jednak pozwala przekształcać twierdzenia o związkach przyczynowo-skutkowych (wyjaśniających interesujące nas zjawiska), w dyrektywy skutecznego działania praktycznego. Każdy praktyk, wyposażony w wiedzę teoretyczną, może posłużyć się nią, zwiększając racjonalność/efektywność swojej pracy. Powinien być jednak spełniony jeden warunek - teoria musi być adekwatną rekonstrukcją fragmentu rzeczywistości, do której odnosi się konkretna praktyka społeczna. Należy dodać, że Petrażycki dopuszczał też tworzenie nauk normatywnych, które zajmują się stanowieniem tak zwanych zasadniczych zasad postępowania, ułatwiających orientację w wartościach moralnych i estetycznych, co ma także duże znaczenie dla kształtowania świadomości społecznej jako regulatora współżycia między ludźmi.

Idee Petrażyckiego były systematycznie doskonalone w ramach nauk społecznych. Wystarczy posłużyć się przykładami prac polskich uczonych: Tadeusza Kotarbińskiego, Andrzeja Malewskiego, Czesława Czapowa, Adama Podgóreckiego. Szczególnie ostatni z wymienionych badaczy poświęcił w zasadzie całe życie naukowe sprawie zwiększania praktycznej użyteczności nauk społecznych. Uważał za niezbędne wyodrębnienie specjalnej kategorii nauk, nazywanych naukami praktycznymi, które, wykorzystując teoretyczne osiągnięcia poszczególnych nauk społecznych, powinny przekształcać ich twierdzenia wyjaśniające w usystematyzowany zbiór twierdzeń praktycznych. „Chodziłoby tu o zestawienie wszystkich możliwych zaleceń 
wynikających z twierdzeń rozmaitych nauk tak, by w oparciu o nie można było przewidywać, jak osiągnąć dany cel” (Podgórecki, 1966: 12). W tym ujęciu różne praktyki społeczne (edukacyjna, zarządzająca produkcją, administracyjna, polityczna, pomoc społeczna) korzystałyby z dyrektyw działania, odpowiednio uporządkowanych, opartych na twierdzeniach teoretycznych, odpowiednio uzasadnionych empirycznie, które byłyby pomocne w wykonywaniu każdej pracy w profesjonalny sposób.

Jak widać, badania i praktyka oparta na dowodach nie są zupełnie nową ofertą wykorzystywania wiedzy naukowej zgromadzonej przez nauki społeczne. Różnice w posługiwaniu się tą wiedzą przedstawiam na rycinie 1.

A

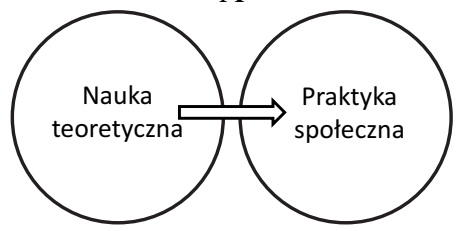

B

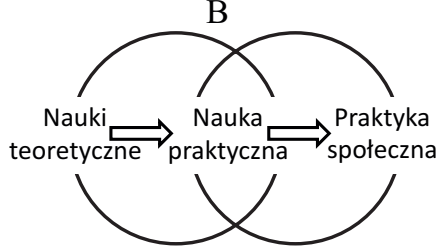

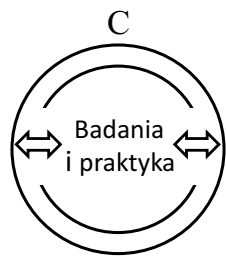

Ryc. 1. Trzy rodzaje regulacji praktyk społecznych przez nauki społeczne

Zgodnie z powyższym rysunkiem pierwsza możliwość „upraktycznienia” wiedzy teoretycznej odnoszącej się do jakiegoś obszaru życia społecznego przebiega niezależnie od zapotrzebowania praktyki. Jednak uczestnicy określonej praktyki po zapoznaniu się z tą wiedzą mogą posługiwać się nią, działając racjonalniej i efektywniej (na rycinie część A). Druga możliwość polega na tym, że między teoretyczną wiedzą naukową a praktyką społeczną wprowadzane jest ogniwo pośrednie - nauki praktyczne. Przetwarzają one wiedzę teoretyczną i wyniki badań z różnych dyscyplin naukowych (aby nie komplikować ryciny, nie zostało na niej to wyraźnie zaznaczone) w spójny system dyrektyw praktycznego działania. Dzięki naukom praktycznym zachowana jest niezależność naukowego poznania rzeczywistości, a jednocześnie dochodzi do wyraźnego zbliżenia nauki i praktyki (na rycinie część B). Ta relacja ulega kompletnemu rozmyciu w przypadku stosowania badań naukowych opartych na dowodach (na rycinie część C). Nauka traci autonomię wobec praktyki, co oczywiście zagraża obiektywizmowi poznania rzeczywistości. Przede wszystkim jednak jest tu całkowicie negowana teoretyczna wiedza naukowa. Zastąpienie jej przez wyniki badań empirycznych sprawia, że cały dorobek teoretyczny nauk społecznych zostaje podważony (Berg, 2019). Dziesiątki lat pracy wybitnych psychologów, socjologów, ekonomistów, antropologów kulturowych uznawane jest za zbędne z punktu widzenia możliwości skutecznego rozwijania społeczeństwa wiedzy (Lingner, 2011). 
Pytanie, jakie trzeba teraz postawić, jest następujące: jeśli teoria naukowa opierająca się na dowodach empirycznych, zebranych poprawnie pod względem metodologicznym, jest mało przydatna dla praktyki, a same dowody mają wartość zasadniczą w jej doskonaleniu, to co złego zawiera w sobie wiedza teoretyczna? Można na nie udzielić wiele odpowiedzi, ale żadna z nich nie może być stanowcza. Są to raczej moje przypuszczenia i dotyczą one kwestii ontologicznej, aksjologicznej oraz epistemologicznej.

Pierwsza odpowiedź może być uznana przez przedstawicieli nauk społecznych za kontrowersyjną. Dotyczy ona sporu między zwolennikami realistycznego i instrumentalnego podejścia do prowadzenia badań naukowych. Moim zdaniem realizm badawczy wymaga zawsze osadzenia wyników badań w ramach szerszego kontekstu ontologicznego, który tworzony jest przez podstawowe założenia - przyjmowane przez badaczy - na temat rzeczywistości, do której odnoszą się wyniki badania. Ta perspektywa badawcza zmusza kolejnych badaczy do wykazania, że koncepcje teoretyczne poprzedników były mniej pełną, mniej precyzyjną, mniej spójną rekonstrukcją rzeczywistości w stosunku do nowej propozycji teoretycznej. Tym samym każde kolejne ujęcie teoretycznego przedstawiania rzeczywistości powinno być coraz prawdziwsze (Montero, 2002). Nowa teoria musi „pokonać” starą poprzez wykazanie jej niedoskonałości, a kryterium rozstrzygającym o wartości każdej z nich jest odniesienie do rzeczywistości.

Słabością realistycznie realizowanych badań naukowych zawsze były przyjęte założenia na temat rzeczywistości. Nie dają się one zweryfikować, stąd w wyniku zniechęcenia jałowymi sporami na ten temat wielu badaczy wybrało instrumentalną opcję badawczą (Gibson, 1994). W tym ujęciu chodziło o poszukiwanie ciągle nowych powiązań między wybranymi elementami rzeczywistości. Pojęcia teoretyczne oznaczające te elementy musiały być zdefiniowane precyzyjnie i nowatorsko. To ułatwiało generowanie heurystycznych hipotez i wykonywanie odpowiednich badań empirycznych (Sundholm, 2004). Nikt z instrumentalistów „nie zawracał sobie głowy” ich ontologicznym sensem. W ten sposób w naukach społecznych zaczęto posługiwać się tymi samymi terminami, przypisywano im jednak odmienne znaczenia (na przykład określenie „osobowość” ma w psychologii co najmniej kilkadziesiąt znaczeń, a niekiedy jeden specjalista z tego zakresu potrafi posłużyć się inną definicją osobowości w każdym z realizowanych projektów badawczych). W ten sposób następuje jednak „oderwanie” teorii naukowych od rzeczywistości. Odkrywane są związki między wyodrębnianymi czynnikami, co jednak nie pozwala zrozumieć, czym one są faktycznie. Metaforycznie można powiedzieć, że teorie „dyskutują” między sobą, 
przekonując się wzajemnie o wartości uzyskanych wyników badawczych, natomiast nie „dyskutują” z rzeczywistością. Różnice między podejściem realistycznym i instrumentalnym przedstawia rycina 2.
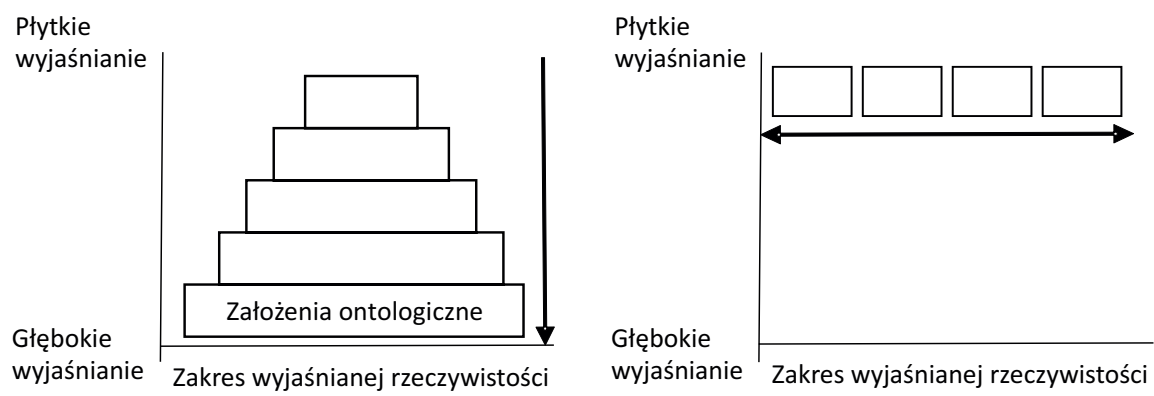

Ryc. 2. Realistyczne i instrumentalne kumulowanie się wiedzy naukowej

W świetle wcześniejszej analizy łatwo można się zorientować, że lewa część ryciny odnosi się do podejścia realistycznego, a prawa do podejścia instrumentalnego prowadzenia badań naukowych. Jeśli prostokąty oznaczają wiedzę naukową, to zdobywanie jej w wariancie realistycznym prowadzi do stopniowego zastępowania teorii mniej prawdziwych przez bardziej prawdziwe (to pogłębianie wiedzy zaznaczono pogrubioną strzałką skierowaną w dół). Natomiast w wariancie instrumentalnym następuje ciągłe poszerzanie wiedzy na bardzo płytkim poziomie. Nie ma tu miejsca na tworzenie teorii wyjaśniających. Prostokąty oznaczają proste modele fragmentów rzeczywistości budowane na podstawie uzyskiwanych danych empirycznych. Właśnie w prawej części ryciny można ulokować procedury oparte na dowodach. Jednakże w tym samym miejscu można umieścić teorie instrumentalne, które nie przywiązują szczególnej wagi do „zakotwiczenia” swoich płytkich wyjaśnień i prognoz w założeniach o realnym świecie. Można przypuszczać, że procedury evidence-based rozwinęły się w efekcie zdominowania nauk społecznych przez podejście instrumentalne do prowadzenia badań (Dunn, Elliott, 2008). Przygotowało ono w każdym razie dobry grunt do upowszechnienia takich badań. Rezygnacja z odniesień ontologicznych sprawiła, że wartość poznawcza teoretycznych modeli empirycznych albo prognostycznych sprowadzona została do wygodnego instrumentu, który uzasadniał kierunki badań empirycznych, ale nie dawał szans na dochodzenie do nowych odkryć naukowych, które zbliżałyby nas do prawdy o rzeczywistości. Z punktu widzenia praktyki podejście instrumentalne i podejście oparte na dowodach niczym szczególnym nie różnią się między sobą - w obu przypadkach 
uzyskujemy wiedzę naukową słabo zintegrowaną (niespójną) i niedającą możliwości do odkrywania coraz bardziej podstawowych prawidłowości rządzących rzeczywistością.

Także druga odpowiedź na postawione wcześniej pytanie może prowokować do polemik. Chodzi mi o status naukowy związany z celami realizowanych praktyk społecznych. Zwolennicy procedur opierania działań praktycznych na dowodach poświęcają dużo uwagi opracowaniu zasad pozyskiwania wiarygodnych danych naukowych, które mają zwiększać racjonalność metod uzyskiwania określonych celów społecznych, natomiast nie są specjalnie zainteresowani wykazaniem, że same cele można ustanawiać na podstawie dowodów naukowych (Oliga, 1996). W innym miejscu starałem się wykazać, że kreatorzy globalnego ładu społecznego też nie mają z tym problemu (Kowalik, 2015). Cele działania są pochodną wartości, dlatego redukują dyskurs o wartościach do minimum, aby w ten sposób ujednolicić życie społeczne. Wartością podstawową dla nich jest racjonalność życia, a tę można określić w naukowy sposób. Nieco przewrotnie powiedziałbym, że globalizacja osiągnie swoje apogeum rozwojowe, gdy ludzie nie będą mieli ani możliwości, ani potrzeby wyboru celów własnych działań, a nawet sensów własnego życia. Nauka ze swoją naukową racjonalnością będzie rozstrzygała za nich, co jest najlepsze, co jest dla nich dobrem. Tym samym globalizacyjna obietnica, że wartością najwyższą będzie w tych warunkach dbałość o indywidualny rozwój każdego człowieka, raczej nie ma szans na urzeczywistnienie.

Osobiście nie jestem przekonany, że wiedza naukowa potrafi jednoznacznie rozstrzygać, jakie należy stawiać cele działania, czyli jakie należy akceptować wartości. Niemniej powinnością nauk społecznych - ciągle aktualną - jest prowokować ludzi do refleksji nad tym, do czego dążą w życiu, a czego powinni się wystrzegać (Li, 2014). Aby to osiągnąć, muszą proponować różnorakie wizje rzeczywistości społecznej. Tu już nie chodzi tylko o poznawanie jej takiej, jaka ona jest, ale ukazywanie jej z punktu widzenia możliwości dalszego jej rozwoju - nazwałbym to podejście słabym konstruktywizmem. Dzięki tej wiedzy ludzie uzyskują możliwość wyboru kierunków i celów działania, stają się też wrażliwsi albo bardziej odporni na oddziaływania zewnętrzne. Przede wszystkim mogą dokładniej dookreślić (wybrać), jakie stany rzeczywistości byłyby dla nich pożądane, a jakie nie (silny konstruktywizm). Mówiąc ogólnie, nauki społeczne, rozwijane w wersji tradycyjnej, niczego nie narzucają, jeśli chodzi o wartości i cele działania. W przeciwieństwie do nich procedury proponujące regulowanie działań społecznych na podstawie dowodów podsuwają 
praktykom gotowe receptury działania wraz z celami i ukrytymi za nimi wartościami społecznymi. Chodzi o to, że przejmując gotowe algorytmy postępowania, jednocześnie zmuszeni jesteśmy do przyjęcia także celów działania, które jednak uzasadnienia naukowego nie mają (Siemianowski, 1976). Nauka tradycyjna jest pod tym względem bardziej demokratyczna - ukazując złożoność rzeczywistości społecznej, a szczególnie przedstawiając różne możliwości jej rozwoju, stwarza szansę wyboru działania przez pojedyncze jednostki i zbiorowości społeczne. W tym miejscu muszę zdecydowanie podkreślić ważną rolę filozofii, która pełni funkcję inspirującą dla innych nauk społecznych w realizacji wyżej przedstawionych zadań (Lane, Oliva, 1998).

Nie chcę głębiej analizować aksjologicznych powodów podważania wartości nauk społecznych - przynajmniej tych, które nie podporządkowują własnych badań procedurom evidence-based - przez zwolenników globalizacji. Jego istotę można przedstawić graficznie tak jak na rycinie 3, odwołując się do teorii preferencji (Kowalik, 1994).

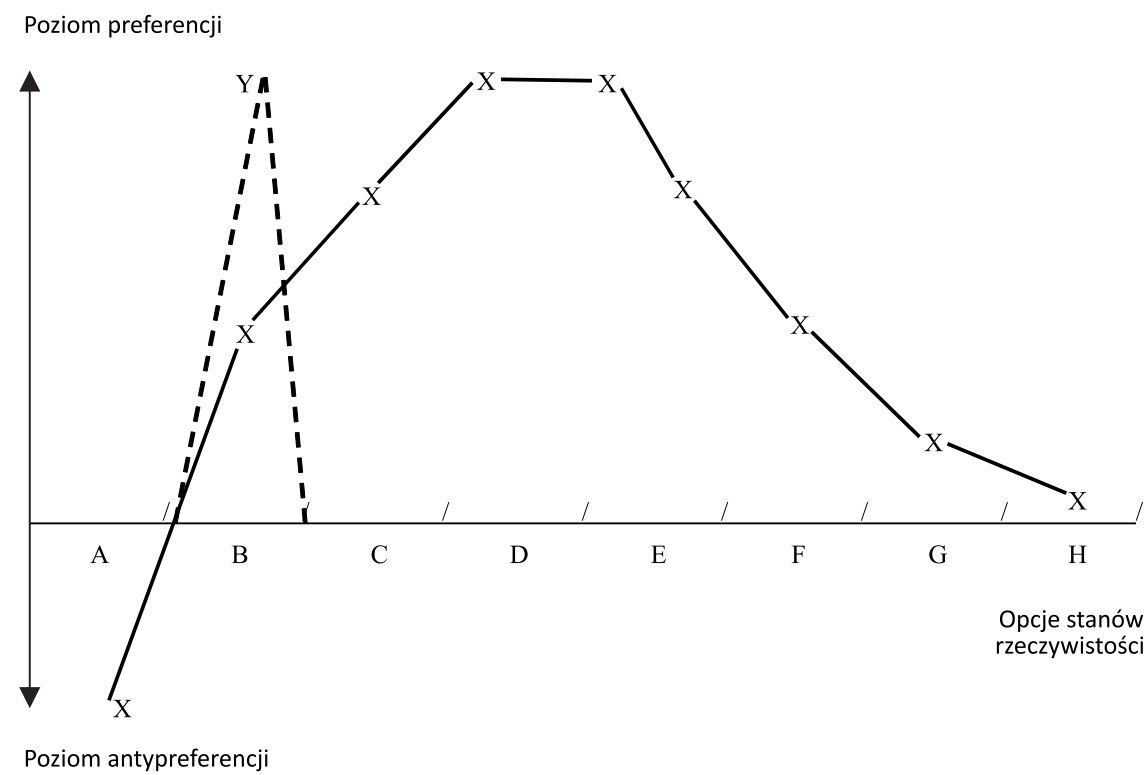

Ryc. 3. Aksjologiczne różnice między wpływem tradycyjnie tworzonej wiedzy naukowej i wiedzy tworzonej na podstawie procedur opartych na dowodach

Na co warto zwrócić uwagę, analizując powyższą rycinę? Przede wszystkim na linii poziomej zaznaczyłem tak zwane opcje różnych możliwych stanów 
rzeczywistości, a na linii pionowej poziom preferowania każdej z nich w porównaniu z pozostałymi. Zaznaczona została też możliwość odrzucenia niektórych stanów (na rycinie opcja A). Preferencje zakładają możliwość wyboru jednej z nich, a więc określają cele działania, które polegają na stworzeniu pożądanego stanu rzeczywistości. Na rysunku zaznaczyłem linią przerywaną preferowaną opcję globalizacyjną, a ciągłą rzeczywiste preferencje ludzi w zakresie pożądanych stanów społecznych. Można przyjąć, że oczekiwaniem zwolenników globalizacji stawianym przedstawicielom nauk społecznych jest dostarczanie wiedzy naukowej, która pomogłaby w skutecznym przekształceniu wszystkich możliwych preferowanych opcji określających stany rzeczywistości (zaznaczonych X-ami) do jednego jej stanu Y. Ten stan jest celem globalizacji (racjonalnie określony ład społeczny), a procedury oparte na dowodach mają ułatwić jego osiągnięcie. W tym miejscu trzeba jednak zauważyć, że osobom, które preferowałyby opcję $\mathrm{H}$, znacznie trudniej byłoby zaakceptować globalizacyjną opcję B niż osobie preferującej opcję C. Prawdopodobnie inne powinny być zastosowane procedury oddziaływania w obu przypadkach, jeśli chodzi o doprowadzenie do preferowania opcji B. Z tym też łączy się problem usuwania ze świadomości ludzi innych stanów rzeczy, poza stanem globalizacyjnie preferowanym. Na rycinie przedstawiono tę sytuację w odniesieniu do opcji A, ale tak naprawdę chodzi o „zepchnięcie” do antypreferencji wszystkich opcji poza opcją B. Nie będę kontynuował omawiania ryciny 3 pod kątem stanowienia celów działania. Ważne jest jedno - o ile można jeszcze wykazać, że dowody empiryczne mogą wzmocnić skuteczność osiągania zakładanych celów społecznych, to trudno uzasadnić naukowo dokonywanie ich racjonalnego wyboru. W ten sposób udzieliłem drugiej odpowiedzi (aksjologicznej) na postawione wcześniej pytanie. Można na ten problem spojrzeć jeszcze z perspektywy epistemologicznej.

Trzecia odpowiedź jest również kłopotliwa dla nauk społecznych. Chcę zwrócić uwagę na problem, który dawniej był dość często podnoszony, ale, z powodu trudności rozwiązania go w konstruktywny sposób, „umarł on ostatnio śmiercią naturalną”. Artykułował go dobitnie William Stern, wskazując na dylemat, przed jakim stoi psychologia (można jednak dodać, że także inne nauki społeczne) w związku z opowiedzeniem się za indywidualistyczną albo uniwersalistyczną wersją wyjaśniania (rozumienia) i przewidywania funkcjonowania ludzi (Kruglanski, 1989). Istotę tego dylematu zaprezentuję na rycinie 4 . 


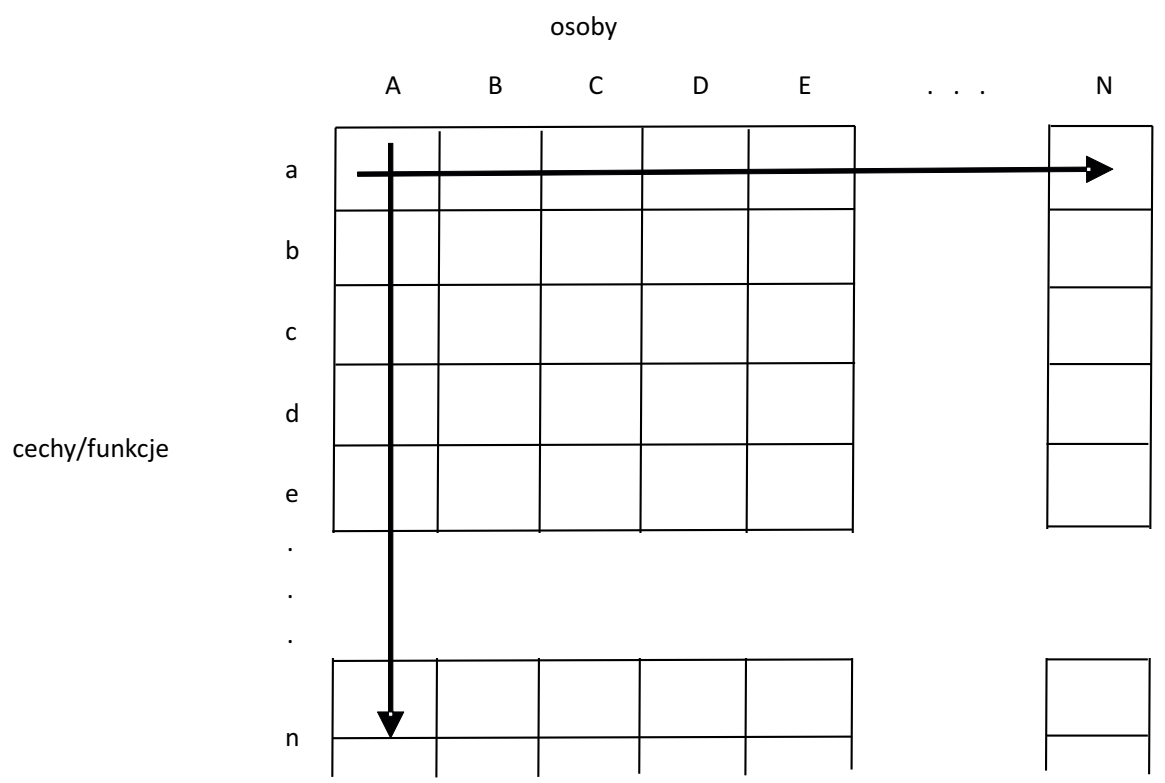

Ryc. 4. Nomotetyczne i idiograficzne podejście do poznania psychologicznego funkcjonowania ludzi

Strzałka pozioma na rycinie oznacza określoną regularność w wyodrębnionym fragmencie funkcjonowania, jaka została stwierdzona u wielu osób (także grup, instytucji) na podstawie wykonanych badań. Odkryta prawidłowość może zostać uznana za uniwersalną charakterystykę ludzi. Na tej podstawie można oczekiwać, że jakakolwiek osoba powinna również podobnie funkcjonować. Każda z nauk społecznych dąży do tego typu odkryć. W tym przypadku regularność dotyczy trwałych związków przyczynowo-skutkowych (albo przynajmniej związków współwystępowania), wyznaczających zmienność cech/funkcji badanych obiektów. Jeśli na dodatek zostanie określona jakaś hierarchia ważności w ramach wykrytych regularności (jedne z nich są nadrzędne w stosunku do innych), to pojawia się możliwość opracowania teorii naukowej, która obejmowałaby swoim zasięgiem fragment badanej rzeczywistości. Oczywiście, dysponując taką wiedzą teoretyczną, można trafnie - przynajmniej to należy założyć - przewidywać przyszłe stany i procesy społeczne oraz postępowania pojedynczych osób (dalszy rozwój, stabilność, destrukcję). Wreszcie można wykazać, że jest ona przydatna do skutecznego projektowania i wywoływania zmian w rzeczywistości. Wiedzą o regularnościach - co prawda stwierdzoną tylko na poziomie empirycznym - posługują się także procedury opierające 
się na dowodach. Jest to jednak wiedza faktualna, wykazująca jedynie, że istnieją regularności - mówiąc najprościej - między bodźcami a reakcjami, czyli między określonymi sposobami oddziaływania na ludzi a ich funkcjonowaniem.

Strzałka pionowa na rycinie 4 sygnalizuje, że cały problem nie jest tak prosty, jak to przyjęło się uważać w nauce. Za jej pomocą zaznaczony został inny sposób poznawania ludzi i zbiorowości. W tym przypadku podważana jest możliwość zupełności poznania obiektów społecznych na podstawie wykrytych uniwersalnych regularności. Pełnię wiedzy o tych obiektach można uzyskać dzięki odkryciu charakterystycznych i niepowtarzalnych połączeń między wszystkimi elementami wchodzącymi w skład każdego z nich. Tak więc osoba A i osoba B nigdy nie będą funkcjonowały w identyczny sposób, gdyż cecha/funkcja „a” u każdej z nich będzie tworzyła odmienne relacje z innymi cechami/funkcjami. Ponieważ obiekt społeczny dąży do utrzymania wewnętrznej spójności (zrównoważenia funkcjonalnego między jego składnikami), regularności interindywidualne mają ograniczoną moc wywierania wpływu - działają one wówczas, gdy przyczyniają się do utrzymania spójności wewnętrznej danego obiektu.

Strzałce pionowej można również nadać inne znaczenie - historyczne. W tym przypadku wyróżnione na rysunku cechy/funkcje „a”, „b”, „,” i dalsze oznaczają ich jakościowe przekształcenia, dokonujące się w procesie rozwoju. Nie wchodząc w szczegóły, chciałbym jedynie podkreślić, że o niepowtarzalności każdego obiektu decyduje jego historia i gromadzone w czasie historycznym doświadczenia (Wallerstein, 2004). Ze względu na różnice w ich nagromadzeniu muszą więc pojawić się odmienne reakcje na wpływy wewnętrzne - indywidualizacja odpowiedzi odnosi się zarówno do jednostek, jak i małych i dużych zbiorowości społecznych. Generalnie można stwierdzić, że również w tym przypadku stosowanie określonej praktyki społecznej wobec osoby/zbiorowości A, znajdującej się na różnych etapach rozwoju, może wywoływać odmienne efekty.

Bez większych trudności można zauważyć, co oznacza dla procedury evidence-based, ale także dla tradycyjnie realizowanych badań naukowych, uznanie idiograficznego punktu widzenia w odniesieniu do wykorzystywania wiedzy naukowej w doskonaleniu praktyki społecznej. Wbrew zapewnieniom badaczy wiedza naukowa nie może zagwarantować trafnego prognozowania efektów oddziaływania na pojedyncze jednostki, ale też różne społeczności. O ile w różnych stanach chorobowych (mających biologiczny charakter) można jeszcze przyjąć, że dynamika zmian zachodzących w organizmach jest zbliżona u większości ludzi i nie jest uwarunkowana oddziaływaniami 
środowiska, to w przypadku stanów psychologicznych i społecznych takie założenie jest nie do przyjęcia. Przekształcanie się tych stanów dokonuje się w sposób niepowtarzalny w różnym czasie i w różnych miejscach, a tym samym strategie oddziaływania muszą być zawsze dostosowane do stanu obecnego, jeśli mają być skuteczne.

Na podstawie powyższej analizy należy wnosić, że proste wzorowanie się na medycynie, jeśli chodzi o zwiększanie skuteczności różnych praktyk społecznych (edukacyjnej, psychologicznej, politycznej, obronnej, ekonomicznej i innych), może jeszcze bardziej osłabić aplikacyjną wartość nauk społecznych. Nie są to zresztą tylko moje spekulacje. Po dwudziestu latach intensywnego upowszechniania praktyki opartej na dowodach okazuje się, że praktycy dość stanowczo odrzucają proponowane im algorytmy skutecznego działania mimo wywieranej na nich presji administracyjnej w tym względzie (Peluso, 2018). Mógłbym odwołać się do wielu wyników badań, które wskazują, że, niezależnie od rodzaju praktyki, tylko około 10-20\% profesjonalistów z różnych dziedzin posługuje się z pełnym przekonaniem procedurami opartymi na dowodach (Kok, Bartholomew, Parcel, Gottlieb, Fernández, 2014; Viglione, Blasco, 2018; Wright, Hibbert, Greenfield, 2018). Nie zawsze praktycy są świadomi metodologicznych źródeł pojawiających się trudności, o jakich wspominałem wyżej. Rozpoznają je w sposób bardziej konkretny. Odwołam się do wyników jednego z badań dotyczącego tego zagadnienia.

Hannes Karin, Staes Filip, Goedhuys Jo, Aertgeerts Bert (2009) badali opinie dużej grupy belgijskich fizjoterapeutów na temat wartości procedur evidence-based, które od 2000 roku zostały zalecone przez Ministerstwo Zdrowia do powszechnego stosowania. Oto najważniejsze ustalenia na temat prowadzenia fizjoterapii opartej na dowodach:

- wyniki badań naukowych określających skuteczność metod fizjoterapeutycznych zazwyczaj dają sprzeczne wyniki, a metaanalizy tych wyników prowadzą zazwyczaj do bardzo ogólnikowych, niespójnych i nieprecyzyjnych postulatów dotyczących postępowania leczniczego;

- czas przeznaczony na zapoznanie się z wynikami badań zmniejsza wydajność pracy, co przyczynia się do zmniejszenia zarobków fizjoterapeutów (posługiwanie się evidence-based nie jest rekompensowane finansowo przez firmy ubezpieczeniowe);

- w ramach procedur opartych na dowodach drastycznie ogranicza się liczbę sesji rehabilitacyjnych (przykładowo pacjent, który powinien otrzymać 60 zabiegów, otrzymuje zgodnie z nową procedurą 9 zabiegów); 
- wprowadzane ograniczenia korzystania z usług fizjoterapeutycznych przyczyniają się do zwiększenia liczby zabiegów operacyjnych i wymuszają posługiwanie się protezami, co jest korzystne dla firm ubezpieczeniowych i zakładów produkujących sprzęt rehabilitacyjny (na przykład przedwcześnie - bez stosowania zabiegów kinezyterapeutycznych wszczepia się protezy stawu biodrowego);

- standardy postępowania rehabilitacyjnego nie uwzględniają w wystarczającym stopniu zróżnicowania zdrowotnego pacjentów, ich postaw wobec określonych zabiegów i warunków życia, które są ważne w kontynuowaniu usprawniania po wyjściu ze szpitala (stosowana w celach diagnostycznych Międzynarodowa Klasyfikacja Funkcjonowania Osób Niepełnosprawnych zaciera nadmiernie różnice między pacjentami i utrudnia uzyskiwanie od nich sprzężeń zwrotnych o postępach rehabilitacji).

Warto w tym miejscu podkreślić, że krytyka praktyków nie jest akceptowana przez propagatorów procedur opartych na dowodach. Na wyraźne dowody wskazujące na odrzucenie tej propozycji zwykle mają oni jedną odpowiedź: „Brak akceptacji praktyków dla evidence-based wynika z ich niepełnej wiedzy o tej procedurze. Trzeba więc z jeszcze większą intensywnością propagować ją wśród profesjonalistów i nakłaniać do ciągłego szkolenia się w tym zakresie”. W ten sposób specjaliści od posługiwania się naukowymi dowodami radzą sobie z brakiem dowodów na skuteczność ich propozycji (Mansell, Carey, 2009; Wainwright, Oates, Edwards, Childs, 2018).

\section{Czym jest dowód dla praktyki? Zamiast zakończenia}

W tym opracowaniu starałem się wykazać, że bezrefleksyjne przyjęcie przez przedstawicieli nauk społecznych oferty globalizacyjnej nazywanej badaniem naukowym opartym na dowodach i praktyką społeczną opartą na dowodach może wyrządzić więcej szkód niż przynieść korzyści zarówno naukom społecznym, jak również działaniom praktycznym odwołującym się do wiedzy naukowej. Niemniej nadal aktualne pozostaje pytanie o to, jak można zwiększać użyteczność praktyczną wiedzy gromadzonej przez nauki społeczne, jeśli odrzucimy globalizacyjny evidence-based. W udzieleniu odpowiedzi na to pytanie niezbędne jest określenie wzajemnych relacji między dowodem a praktyką.

Nauki społeczne dopuszczają posługiwanie się różnymi rodzajami dowodów (Brendtro, Mitchell, 2010). Przykładowo prawo dopuszcza przeprowadzenie czynności dowodowych, polegających na przedstawieniu 
dowodu prawdy, będącego potwierdzeniem albo zaprzeczeniem dokonania przez kogoś czynu przestępczego. Przepisy prawa określają, co można uznać za dowód i w jaki sposób można się nim posługiwać w rozstrzyganiu prawdziwości zeznań sądowych (Wenzel, Okimoto, Feather, Platow, 2008). Na tej podstawie formułowany jest wyrok sądowy. Można go podważać, ale to sąd ustanawia swoją decyzją, co jest prawdą w konkretnej sprawie. W tym przypadku decyzje te uzasadniają wybór działania wobec podsądnego. Gdyby dowodów jednak nie było, to i tak sąd musiałby podjąć decyzję w sprawie. Czy w tym przypadku chodzi o taki sam rodzaj dowodów, jakie postulują badania oparte na dowodach? Można mieć wątpliwości, czy fakty zgromadzone w pojedynczym śledztwie mogą być uznane zawsze za dowód, który ukierunkuje naukowo postępowanie sądu, a potem działania służb penitencjarnych. W tym ujęciu dowód jako obiektywny fakt można traktować jako argument o określonej wadze, który przeciwstawiany jest argumentom przeciwstawnym. W końcu to ludzie (sędziowie, ławnicy) decydują o ich znaczeniu w dochodzeniu do poznania prawdy (doświadczenie życiowe jako wskazówka dla praktycznego działania) (Cotterrell, 1998).

A oto inne przykłady posługiwania się dowodami w praktyce. Na bazie solidnych badań naukowych w Stanach Zjednoczonych została opracowana solidna technologia przetwarzania odpadów miejskich w nawozy, które miały użyźniać pola. Okazało się, że w ciągu ostatnich lat zmieniła się struktura chemiczna tych odpadów - wzrosła w nich ilość substancji trujących, co skutkuje pojawieniem się na rynku niezdrowej żywności (Rakel, 2004). Można więc powiedzieć, że w tym przypadku dowodem może być błąd w opracowaniu metod utylizacyjnych, które trzeba zmienić. Z błędu nie wynika jednak wskazówka, jak to zrobić. Rozwój obecnej pandemii także wskazuje na ten sam problem - w różnych krajach stosuje się różne procedury jej zwalczania i być może wkrótce okaże się, że wszystkie były błędne. A oto inny przykład. Również w Stanach Zjednoczonych podjęto próby racjonalizacji zakupów książek do bibliotek naukowych (Strothmann, Rupp-Serrano, 2020). Opierając się na procedurze evidence-based, pozyskiwano książki, które we wcześniejszych badaniach sondażowych były często wybierane jako interesujące i warte przeczytania. Okazało się jednak, że zakupione w taki sposób książki naukowe nie były wcale częściej wypożyczane w porównaniu z książkami uznanymi w sondażu za mało atrakcyjne. Powody rozbieżności były różne. Bibliotekarze nie kierowali się wyłącznie przy zakupach wynikami badań. Brali pod uwagę ceny książek (za te same pieniądze można było nabyć więcej książek), koniecznością uzupełniania serii książkowych, własnym doświadczeniem na temat zainteresowań czytelniczych. Można powiedzieć, że zamiast 
dowodów mieli racjonalne argumenty, które ukierunkowały ich wybory. Wreszcie możliwość zakupu i wypożyczenia książek przez Internet zmieniła wcześniejsze ustalenia dotyczące trafnego pozyskiwania publikacji do bibliotek. Okazało się, że racje wynikające ze stosowanej praktyki pozwalają znacznie szybciej reagować na zmiany zapotrzebowania rynku niż dowody uzyskane z pracochłonnych badań empirycznych.

Na podstawie mnóstwa podobnych ustaleń, ale też kierując się własnym doświadczeniem zawodowym, sformułowałem własną propozycję doskonalenia praktyk społecznych opartych na wiedzy naukowej. Skrótowo można ją przedstawić w następujących punktach. Po pierwsze, w zasadzie żadna praktyka społeczna nie jest regulowana wyłącznie wiedzą naukową. Po drugie, należy uznać, że są trzy rodzaje wiedzy regulującej tę praktykę: a) doświadczenie zawodowe, które jest rodzajem wiedzy zdroworozsądkowej, zindywidualizowanej i ciągle wzbogacanej, b) wiedza zinstytucjonalizowana, tworzona przez tradycję, przepisy i reguły obowiązujące w instytucjach, w ramach których realizowana jest określona praktyka, oraz c) wiedza naukowa odnosząca się do opisu i wyjaśnienia sposobu wykonywania różnych praktyk społecznych. Po trzecie, uzyskamy zwiększanie niezawodności (brak błędów) i efektywności (uzyskiwanie maksymalnego efektu przy minimalnych kosztach) danej praktyki, jeśli praktykom zostanie zaoferowana nowa wiedza naukowa, która będzie różniła się od posiadanej dotąd wiedzy na tyle, aby skłaniać ich do zmodyfikowania własnej działalności, Po czwarte, praktyczną wartość nowej wiedzy naukowej weryfikują sami praktycy - pozytywne doświadczenia związane z jej stosowaniem przez profesjonalistów i osoby korzystające z ich usług powinny przyczyniać się do utrwalania nowych metod praktycznego działania. Po piąte, zadaniem badaczy reprezentujących nauki społeczne powinno być intensywniejsze rozwijanie koncepcji teoretycznych i badań empirycznych odnoszących się do różnego rodzaju praktyk społecznych - dowodem wartości tak rozwijanej wiedzy naukowej zawsze będzie przekształcenie się starej praktyki w nową (Kowalik, 1989).

Wiem z własnej praktyki jako naukowca, że powyższa propozycja wzmacniania aplikacyjnych możliwości nauk społecznych nie zdobyła uznania przynajmniej w środowisku psychologów. Prawdę mówiąc, straciłem już wiarę w jej wartość i nadzieję na uznanie jej za przynajmniej alternatywę badań i praktyki opartej na dowodach. Jednak w ostatnich latach zostałem zaskoczony zmianą w poglądach, jakie oficjalnie sformułowało Amerykańskie Towarzystwo Psychologiczne. Do 2006 roku lansowało ono identyczny wzorzec prowadzenia badań naukowych i wykonywania zawodu psychologa z wzorcem medycznym. W tymże roku nastąpiła zasadnicza zmiana 
stanowiska tej prominentnej instytucji (Hamill, Wiener, 2018). Nowa wykładnia praktyki opartej na dowodach ma przypominać stołek z trzema nogami. Pierwszą z nich tworzą oczywiście dowody naukowe, drugą - indywidualne kompetencje i doświadczenie zawodowe, trzecią zaś indywidualne właściwości użytkowników danej praktyki (szczególnie postawy, jakie tworzą wobec działań do nich kierowanych). Znika więc stopniowo z nauk społecznych praktyka traktowana jako chybotliwy stołek oparty na jednej nodze (naukowe dowody empiryczne). Czekam na ten moment, kiedy do trzech nóg dodana zostanie stołkowi noga czwarta w postaci naukowej wiedzy teoretycznej.

\section{Literatura}

Arystoteles (1990). Dzieła wszystkie, t. 2. Warszawa: Państwowe Wydawnictwo Naukowe. Audi, R. (2004). Perception and consciousness. W: I. Nüniluoto, M. Sintonen, J. Woleński (red.), Handbook of Epistemology (s. 57-107). Dordrecht: Springer.

Aument, K., Conley, Q. (2018). Transforming theory to practice. Integrating evidence-based practices in human performance improvement. Performance Improvement, 57, $26-32$.

Barlow, N. (1958). The Autobiography of Charles Darwin 1809-1882. London: Collins.

Beauchamp, S., Drapeau, M., Dionne, C. (2015). The development of practice guidelines in the social and human sciences. Canadian Psychology, 56, 357-357.

Bendle, M.F. (2001). Being critical in globalized world. Australian Psychologist, 36, 81-83.

Berg, H. (2019). Evidence-based practice in psychology fails to be tripartite. A conceptual critique of the scientocentrism in evidence-based practice in psychology. Frontiers in Psychology, 10, 1-15.

Böhme, G. (1979). Alternatives in science - alternatives to science? W: H. Nowotny, $\mathrm{H}$. Rose (red.), Counter-movements in the Sciences. The sociology of the alternatives to big science (s. 105-125). London: D. Reidel Publishing Company.

Böhme, G., Stehr, N. (1986). The Knowledge Society. Dordrecht: D. Reidel Publishing Company.

Brendtro, L.K., Mitchell, M.L. (2010). Weighing the evidence. From chaos to consilience. Reclaiming Children and Youth, 19, 1-5.

Brohman, J. (1995). Economism and critical silences in development studies. A theoretical critique of neoliberalism. Third World Quarterly, 16, 297-318.

Brzeziński, J. (1978). Metodologiczne i psychologiczne wyznaczniki procesu badawczego w psychologii. Poznań: Wydawnictwo Naukowe UAM.

Bunge, M. (1985). Treatise on Basic Philosophy. Life science, social science and technology. Dordrecht: D. Reidel Publishing Company.

Burgess, A., Chang, J., Nakamura, B.J., Izmirian, S., Okamura, K.H. (2016). Evidence-based practice implementation within a theory of planned behaviour framework. Journal of Behavioral Health Services and Research, 1, 647-665.

Cairney, P. (2016). The Politics of Evidence-Based Policy Making. London: Macmillan Publishers. 
Caselli, M. (2012). Trying to Measure Globalization. New York: Springer.

Cavallo, R.E. (1979). The Role of Systems Methodology in Social Science Research. Boston: Kluwer.

Coleman, J.S. (1968). Wstęp do socjologii matematycznej. Warszawa: Państwowe Wydawnictwo Ekonomiczne.

Cotterrell, R. (1998). Why must legal ideas be interpreted sociologically? Journal of Law and Society, 25, 171-192.

Dunn, D.S., Elliott, T.R. (2008). The place and promise of theory in rehabilitation psychology. Rehabilitation Psychology, 53, 254-267.

Ercikan, K., Roth, W.M. (2016). Qualitative and quantitative evidence in health. The critics view. W: K. Olson, R.A. Young, I.Z. Schultz (red.), Handbook of Qualitative Health Research for Evidence-based Practice (s. 77-90). New York: Springer.

Eustace, S. (2018). Technology-induced bias in the theory of evidence-based medicine. Journal of Evaluation in Clinical Practice, 24, 945-949.

Gay, P. (2003). Freud. Życie na miarę epoki, tłum. H. Jankowska. Poznań: Zysk i S-ka.

Gibson, E.J. (1994). Has psychology a future? Psychological Science, 5, 69-75.

Giddens, A. (2009). Europa w epoce globalnej, tłum. M. Klimowicz, M. Habura. Warszawa: Wydawnictwo Naukowe PWN.

Greenhalgh, T. (2001). How to Read a Paper. The basics of evidence-based medicine. London: BMJ Books.

Hallowell, N., Lawton, J., Gregory, S. (2005). Reflections on Research. The realities of doing research in the social sciences. Berkshire: Open University Press.

Hamill, N.R., Wiener, K.K. (2018). Attitudes of psychologists in Australia towards evidence-based practice in psychology. Australian Psychologist, 53, 477-485.

Karin, H., Filip, S., Jo, G., Bert, A. (2009). Obstacles to the implementation of evidence-based physiotherapy in practice. A focus group-based study in Belgium (Flanders). Physiotherapy Theory and Practice, 25, 476-488.

Kok, G., Bartholomew, K., Parcel, G.S., Gottlieb, N.H., Fernández, M.E. (2014). Finding theory - and evidence-based alternatives to fear appeals. Intervention mapping. International Journal of Psychology, 49, 98-107.

Kowalik, S. (1989). Upośledzenie umysłowe. Teoria i praktyka rehabilitacji. Warszawa: Państwowe Wydawnictwo Naukowe.

Kowalik, S. (1994). Zachowania konsumenckie - teoria preferencji - reklama. Ruch Prawniczy, Ekonomiczny i Socjologiczny, 52, 97-111.

Kowalik, S. (2006). Czy potrzeba nam autorytetów na świecie? Ruch Prawniczy, Ekonomiczny i Socjologiczny, 67, 191-208.

Kowalik, S. (2015). Uśpione społeczeństwo. Szkice z psychologii globalizacji. Warszawa: Wydawnictwo Akademickie „Sedno”.

Kruglanski, A. (1989). Lay Epistemics and Human Knowledge. New York: Springer.

Kurz-Milcke, E. (2004). The authority of representation. W: E. Kurz-Milcke, G. Gigerenser (red.), Experts in Science and Society (s. 281-301). New York: Kluwer Academic Publishers.

Lane, D.C., Oliva, R. (1998). The greater whole. Towards a synthesis of system dynamics and soft system methodology. European Journal of Operational Research, 107, $214-235$.

Li, D. (2014). Value Theory. A research into subjectivity. Berlin: Springer. 
Lubeck, S., Jessup, P. (2001). Globalisation and its impact on early years funding and curriculum. Reform initiatives in England and the United States. W: T. David (red.), Promoting Evidence-based Practice to Early Childhood Education. Research and its implications (s. 227-249). Oxford: Elsevier Science Ltd.

MacCoun, R.J. (2015). The epistemic contract. Fostering an appropriate level of public trust in expert. W: B.H. Bornstein, A. Tomkins (red.), Motivating Cooperation and Compliance with Authority (s. 13-36). Heidelberg: Springer.

Malcolm, K.T., Taylor, K.K., Mitchell, J., Saile M., Heatly, M., Alpert-Gillis, L.J. (2019). Why, what, and how. Training community clinicians on evidence-based practice for youth mental health. Training and Education in Professional Psychology, 13, 279-286.

Mansell, W., Carey, T.A. (2009). A century of psychology and psychotherapy. Is an understanding of control the missing link between theory research and practice? Psychology and Psychotherapy. Theory, Research, and Practice, 82, 337-353.

Marttila, T. (2016). Post-fundational Discourse Analysis. From political difference to empirical research. New York: Palgrave Macmillan.

Montero, M. (2002). On construction of reality and truth. Towards epistemology of community social psychology. American Journal of Community Psychology, 30, 571-584.

Montori, V.M., Guyatt, G.H. (2008). Progress in evidence-based medicine. Journal of the American Medical Association, 300, 1814-1816.

Møller, V., Huschka, D. (2009). Challenges for quality-of-life studies in the Millennium. W: V. Møller, D. Huschka (red.), Quality of Life and the Millennium Challenge (s. 1-12). New York: Springer.

Nowotny, P. (1979). Science and its crisis. Reflection on antiscience. W: H. Nowotny, $\mathrm{H}$. Rose (red.), Counter-movements in the Sciences. The sociology of the alternatives to big science (s. 1-27). London: D. Reidel Publishing Company.

Oakley, A. (2002). Social science and evidence-based everything. Educational Review. 54, 277-286.

Oliga, J.C. (1996). Power, Ideology, and Control. New York: Plenum Press.

Olson, K., Young, R.A., Schultz, I.Z. (2016). Using qualitative health research to transform the nature of evidence. W: K. Olson, Young R.A., I.Z. Schultz (red.), Handbook of Qualitative Health Research for Evidence-based Practice (s. 3-6). New York: Springer.

Peck, J., Tickell, A. (2002). Neoliberalizing space. Antipode, 2, 380-404.

Peluso, P.R. (2018). Adlerian evidence-based practice research. Response to Sperry. The Journal of Individual Psychology, 74, 265-271.

Petras, J. (1999). Globalization. A critical analysis. W: R.M. Chilcote (red.), The Political Economy of Imperialism. New York: Kluwer.

Petrażycki, L. (1985). O nauce, prawie i moralności. Pisma wybrane. Warszawa: Państwowe Wydawnictwo Naukowe.

Podgórecki, A. (1966). Zasady socjotechniki. Warszawa: Wiedza Powszechna.

Rakel, H. (2004). Scientists as expert advisors. Science cultures versus national cultures? W: E. Kurz-Milcke, G. Gigerenser (red.), Experts in Science and Society (s. 3-25). New York: Kluwer Academic Publishers.

Ruane, F. (2014). Public intellectuals in times of crisis. The role of academia. W: M. Corcoran, K. Lalor (red.), Reflections on Crisis. Dublin: RIA. 
Sackett, D.L., Rosenberg, W.M., Gray, J.A., Haynes, R.B., Richardson, W.S. (1996). Evidence-based medicine. What is it and what in isn't. British Medical Journal, 312, 71-72.

Scholte, J.A. (2000). Globalization. A critical introduction. New York: Palgrave McMillan. Shapin, S. (1993). Historia nauki i jej socjologiczne rekonstrukcje. W: B. Barnes, D. Bloor (red.), Mocny program socjologii wiedzy (s. 373-440), tłum. Z. Jankiewicz, J. Niżnik, W. Szydłowska, M. Tempczyk. Warszawa: Wydawnictwo IFiS PAN.

Sherwood, V.A. (2019). Does evidence-based treatment exist in the mental disciplines? Journal of Theoretical and Philosophical Psychology, 39, 239-253.

Siemianowski, A. (1976). Poznawcze i praktyczne funkcje nauk empirycznych. Warszawa: Państwowe Wydawnictwo Naukowe.

Sindermann C.J. (1985). The Jay of Science. New York: Springer.

Singh, N.N., Oswald, D.P. (2004a). Evidence-based practice. Part I. General methodology. Journal of Child and Family Studies, 13, 129-142.

Singh, N.N., Oswald, D.P. (2004b). Evidence-based practice. Part II. A specific methodology. Journal of Child and Family Studies, 13, 255-262.

Sintonen, M., Kiikri, M. (2004). Scientific discovery. W: I. Nüniluoto, M. Sintonen, J. Woleński (red.), Handbook of Epistemology (s. 205-253). Dordrecht: Springer.

Straus, S.E., Richardson, W.S., Glasziou, P., Haynes, R.B. (2005). Evidence-based Medicine. How to practice and teach. London: Elsevier Health Sciences.

Strothmann, M., Rupp-Serrano, K. (2020). A comparative analysis of evidence-based selection, professional selection, and selection by approval plan. Library Resources and Technical Services, 64, 15-25.

Sundholm, G. (2004). Antirealism and the roles of truth. W: I. Nüniluoto, M. Sintonen, J. Woleński (red.), Handbook of Epistemology (s. 437-466). Dordrecht: Springer.

Thyer, B.A., Pignotti, M. (2015). Science and Pseudoscience in Social Work Practice. New York: Springer Publishing Company.

Ullrich, O. (1979). Counter-movements and the sciences. Theses supporting counter-movements to "scientisation of the world". W: H. Nowotny, H. Rose (red.), Counter-movements in the Sciences. The sociology of the alternatives to big science (s. 127-146). London: D. Reidel Publishing Company.

Viglione, J., Blasco, B.L. (2018). The differential impacts of probation staff attitudes on use of evidence-based practices. Psychology, Public Policy, and Law, 4, 449-458.

Wainwright, D.W., Oates, B.J., Edwards, H.M., Childs, S. (2018). Evidence-based information systems. A new perspective and a road map for research-informed practice. Journal of the Association for Information Systems, 19, 1035-1063.

Wallerstein, I. (2004). Koniec świata jaki znamy. Warszawa: Wydawnictwo Naukowe „Scholar”.

Walter, W. (2004). Experts' discourses as judicial drama or bureaucratic coordination. Family debate in the United States and Germany. W: E. Kurz-Milcke, G. Gigerenser (red.), Experts in Science and Society (s. 27-46). New York: Kluwer Academic Publishers.

Wenzel, M., Okimoto, T.G., Feather, N.T., Platow, M.J. (2008). Retributive and restorative justice. Law and Human Behavior, 32, 375-389.

Wheen, F. (2005). Karol Marks. Biografia, tłum. D. Cieśla. Warszawa: W.A.B.

Wright, A.L., Hibbert, P., Greenfield, G. (2018). Student understandings of evidencebased management. Ways of doing and being. Academy of Management Learning and Education, 17, 453-473. 